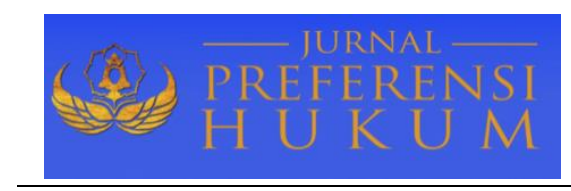

Jurnal Preferensi Hukum | ISSN: XXXX | E-ISSN: XXXX

Vol. 1, No. 2 - September 2020, Hal. 28-32| Available Online at https://www.ejournal.warmadewa.ac.id/index.php/juprehum

DOI: http://doi.org/10.22225/jph.v1i2.2338.28-32

\title{
PERAN BADAN PENYELESAIAN SENGKETA KONSUMEN (BPSK) DALAM PENYELESAIAN SENGKETA KONSUMEN (STUDI KASUS: PUTUSAN BPSK BADUNG NO.01/AP/BPSK/IV/2016)
}

\author{
Arianto Hulu, A.A. Laksmi Sagung Dewi, Ni Made Sukaryati Karma \\ Fakulatas Ilmu Hukum Universitas Warmadewa, Denpasar - Bali, Indonesia \\ ariantohoelaw@gmail.com
}

\begin{abstract}
Abstrak
Indonesia dengan jumlah penduduk terbanyak ke empat didunia menjadi pangsa pasar yang menggiurkan bagi pelaku usaha. Namun potensi tersebut tidak luput dari hal negatif dimana pelaku usaha kerap hanya menjadikan konsumen sebagai objek dari kegiatan bisnisnya tanpa memperhatikan kualitas produk yang dipasarkan sehingga konsumen mendapat kerugian. Menyikapi fenomena tersebut sehingga dibentuk Badan penyelesaian Sengketa Konsumen (BPSK) sebagai sarana alternatif penyelesaian sengketa antara Pembeli dan Penjual dengan tujuan menyelesaikan sengketa diantara kedua belah pihak secara non litigasi secara efektif dan efisien. Organisasi ini bukanlah sistemis, tetapi mempunyai fungsi membereskan konflik yang terjadi antara produsen dengan pembeli secara non litigasi. Penelitian ini dilakukan dengan tujuan mendeskripsikan bagaimana bentuk perlindungan hukum konsumen terhadap pelaku usaha dan bagaimana peran BPSK dalam penyelesaian sengketa konsumen. Metode penelitian yang digunakan dalam penulisan ini adalah metode penelitian hukum normatif. Penelitian ini menunjukkan bahwa perlindungan hukum konsumen terhadap pelaku usaha diatur dalam pasal 1 angka 3 UU No. 8 tahun 1999 mengenai perlindungan konsumen yang menyatakan kalau pelaku usaha itu merupakan orang keseluruhan atau individu ataupun suatu badan usaha yang didasarkan pada hukum atau tidak serta tempat melaksanakan kegiatan tersebut di daerah NKRI. Selain itu, BPSK memiliki peran dalam melaksanakan proses dan penuntasan konflik konsumen melalui cara mediasi, arbitrase atau konsiliasi dengan kesempatan yang diberikan mulai dari konsultasi perlindungan konsumen, pengawasan dalam penerapan perjanjian, membuat laporan ke penyidik apabila ada indikasi pelanggaran hukum, menerima pengaduan, melakukan kajian dan analisis konflik yang terjadi, memanggil para pihak, saksi maupun setiap individu yang mengetahui sebuah peristiwa pelanggaran hukum.
\end{abstract}

Kata Kunci: Hukum Konsumen; Konsumen; Pelaku Usaha; Penyelesaian Sengketa Konsumen

\begin{abstract}
Indonesia, with the fourth largest population in the world, is a large market share for business actors. However, this potential is not free from negative things where business actors often only make consumers the object of their business activities without paying attention to the quality of the products being marketed so that consumers suffer losses. Responding to this phenomenon, the Consumer Dispute Resolution Agency (BPSK) was formed as an alternative means of dispute resolution between Buyers and Sellers with the aim of resolving disputes between the two parties in an effective and efficient non-litigation manner. This organization is not systemic but has the function of resolving conflicts that occur between producers and buyers on a non-litigation basis. This research was conducted with the aim of describing the forms of consumer legal protection for business actors and the role of BPSK in resolving consumer disputes. The research method used in this paper was a normative legal research method. This research showed that consumer legal protection for business actors is regulated in article 1 number 3 Law No. 8 of 1999 regarding consumer protection which states that a business actor is an entire person or individual or a business entity based on law or not and the place to carry out these activities in the territory of the Republic of Indonesia. In addition, BPSK has a role in carrying out the process and resolving consumer conflicts through mediation, arbitration or conciliation with opportunities ranging from consumer protection consultations, supervision in the application of agreements, making reports to investigators if there are indications of legal violations, receiving complaints, conducting studies and analysis of conflicts that occurred, summoning the parties, witnesses and any individual who is aware of an incident of law violation.
\end{abstract}




\section{PENDAHULUAN}

Sejarah mencatat bahwa Indonesia telah lama dikunjungi oleh para pedagang dari berbagai negara di dunia. Kekayaan alam indonesia menjadi daya tarik bagi para saudagar dengan harapan prospek ekonomi yang tinggi (Tumantara, 2016). Hal itu diperkuat dengan tingginya pertumbuhan jumlah penduduk Indonesia setiap tahunnya sehingga menjadikan Indonesia Negara dengan Penduduk terbanyak keempat didunia. Potensi ini menjadikan pangsa pasar yang menjanjikan bagi pelaku usaha baik dalam negeri maupun luar negeri untuk menjual produknya. Akibat dari Pesatnya perkembangan di era globalisasi sehingga perdagangan bebas mendominasi aktivitas bisnis baik barang maupun jasa (Redjeki, 2002).

Semakin meningkatnya pembangunan dan tumbuhnya ekonomi menyebabkan munculnya berbagai jenis produk barang/ jasa yang dapat memenuhi akan kebutuhan konsumen. Semakin majunya iptek dan saluran komunikasi yang tanpa batas turut mendorong pelebaran lintasan gerakan jual beli produk atau layanan ke berbagai daerah tanpa adanya batas-batas wilayah suatu Negara. Keadaan tersebut memberikan dampak dalam memenuhi kebutuhan masyarakat sebab keperluannya akan suatu produk atau layanan yang dikehendaki dengan mudah tercukupi dan makin banyak kesempatan dalam memilah-milah klasifikasi produk atau layanan yang dikehendaki oleh pembeli berdasarkan kesanggupannya. Kemajuan sektor perdagangan sekarang ini amat gesit dan hal ini mempunyai kaitan erat dengan aktivitas perdagangan baik produk mapaun layanan dan ditopang oleh pertumbuhan ekonomi dalam mapun luar negeri. Di lain sisi, keadaan dan fenomena tersebut turut memberikan nilai positif maupun negatif dimana kadang berdampak pada posisi penjual dan pembeli yang tidak setara, dimana pembeli cenderung dianggap obyek kegiatan perdagangan oleh pedagang demi meraup laba sebanyak-banyaknya dan pembuatan perikatan antara penjual dan pembeli yang tidak adil bagi pembeli.

Masyarakat yang beragam menyebabkan pelaku usaha seringkali melakukan kegiatan pemasaran dan distribusi produk barang atau jasa dengan strategi yang paling efektif demi memenuhi kebutuhan konsumen yang sangat beragam tersebut demi meraih keuntungan dan mengabaikan keselamatan konsumen. Konsumen dapat dirugikan melalui informasi yang tidak sesuai, pemalsuan produk dan kualitas produk (Kurniawan, 2011). Persoalan utama yang dihadapi oleh konsumen adalah kesadaran akan keutamaan penyelamatan bagi pembeli. Di banyak persoalan yang merugikan pembeli telah diselesaikan namun tidak adil sehingga malah merugikan konsumen.

Kesadaran para konsumen dan pendidikan yang rendah menjadi titik lemah yang dengan mudah dimanfaatkan oleh pelaku usaha demi meraup untung (Krisyanti, 2009). Oleh sebab itu, Perlindungan bagi konsumen memiliki peranan yang paling utama demi menyetarakan posisi pembeli dengan penjual. Saat ini, penyelesaian sengketa antara konsumen dan pelaku usaha dapat diselesaikan dengan jalur peradilan maupun di luar peradilan.

Kehadiran aturan hukum bagi aktivitas jual beli produk maupun layanan antara penjual dan pembeli bertujuan menjadi payung yuridis yang kokoh bagi eksekutif maupun organisasi nirlaba yang berkonsentrasi mengurus persoalan ini demi meningkatan pemahaman masyarakat yang dilakukan secara efektif dan efisien. Tetapi, upaya untuk menyadarkan pelaku usaha tidaklah mudah sebab pelaku usaha memiliki prinsip ekonomi yaitu dengan modal yang sekecil-kecilnya namun meraih keuntungan yang sebesar-besarnya sehingga konsumen dapat dirugikan baik secara langsung maupun tidak langsung (Shidarta, 2000).

Dibentuknya Badan Penyelesaian Sengketa Konsumen (BPSK) menjadi angin segar bagi perlindungan konsumen. Dimana BPSK merupakan sebuah lembaga non struktural dan berkedudukan di Daerah Tingkat II atau Kabupaten/ Kota memiliki tugas pokok dan fungsi adalah menuntaskan apabila ada konflik antara pengguna suatu produk atau layanan dengan produsen atau penjual secara non litigasi (Akhyar, Matnuh, \& Hardianto, 2015; Samosir, 2018; Yatini \& Safitri, 2019). Susunan keanggotaanya dari unsur eksekutif, penjual dan pedagang. Kehadiran lembaga ini didambakan mampu mengakomodir kepentingan masyarakat atau konsumen yang menghindari proses penyelesaian sengketa melalui pengadilan serta untuk mengurangi beban tumpukan perkara di pengadilan. Langkah ini merupakan salah satu terobosan baru dan diharapkan dapat membantu serta menunjang kegiatan penyelamatan bagi pengguna atau pembeli di negara ini. Perkembangan aktivitas ekonomi penduduk kita sekarang ini sehingga membuat peran BPSK sebagai media alternatif 
penyelesaian sengketa sehingga dibutuhkan di daerah-daerah yang mempunyai intensitas kegiatan ekonomi yang cukup tinggi.

Berdasarkan latar belakang permasalahan tersebut penelitian ini dilakukan dengan tujuan mendeskripsikan bagaimana bentuk perlindungan hukum konsumen terhadap pelaku usaha dan bagaimana peran BPSK dalam penyelesaian sengketa konsumen.

\section{METODE PENELITIAN}

Penulisan riset ilmiah ini memakai riset ilmiah hukum normatif dengan menggunakan metode pendekatan masalah penalaran kasus. Sumber data penelitian ini adalah Undang-Undang, artikelartikel hukum, dan pendapat para ahli hukum. Data yang dibutuhkan dikumpulakan dengan menggunakan metode kepustakaan. Data yang terkumpul dianalisis menggunakan metode kualitatif dan disajikan secara deskriptif.

\section{HASIL DAN PEMBAHASAN}

\section{Perlindungan Hukum Konsumen terhadap Pelaku Usaha}

Negara Kesatuan Repulik Indonesia merupakan Negara Hukum dan istilah Negara Hukum secara konstitusional telah disebutkan secara tegas dalam Undang-Undang Dasar Negara Kesatuan Republik Indonesia 1945. Dimana setiap warga negara akan mendapatkan perlindungan hukum secara adil dengan kedudukan yang sama didepan hukum tanpa memandang suku, agama, ras, dan golongan.

Beberapa ahli telah mengemukakan pendapatnya perihal maksud dari Perlindungan Hukum, diantaranya:

1. Satjipto Raharjo mengatakan bahwa perlindungan hukum itu merupakan kumpulan dari semua aturan hak asasi manusia untuk bisa menikmati hak- hak yang memang diberikan oleh aturan yang ada.

2. Philipus M. Hadjon menyatakan bahwa perlindungan hukum itu merupakan perlindungan yang bersangkutan dengan kehidupan seseorang yang memang harus dan wajib didasarkan pada aturan.

3. CST Kansil menyebutkan, Perlindungan Hukum itu salah satu cara yang disediakan hukum demi merasakan hal yang baik dan nyaman dalam menjalani kehidupan bermasyarakat.

Menurut Shidarta (2000), Perlindungan Konsumen merupakan asas dan kaidah hukum pengatur para pihak terkait suatu barang atau jasa. Aturan perlindungan konsumen merupakan aturan dan hukum bagi konsumen dan produsen demi terwujudnya perlindungan hukum bagi konsumen.

Pasal 1 angka 3 UU No. 8 tahun 1999 mengenai perlindungan konsumen, menyatakan kalau pelaku usaha itu merupakan orang keseluruhan atau individu ataupun suatu badan usaha yang didasarkan pada hukum atau tidak serta tempat melaksanakan kegiatan tersebut di daerah NKRI.

Dihadapan hukum pelaku usaha mempunyai perlindungan dalam menjalankan bisnisnya demi terhindar dari perbuatan curang oknum konsumen yaitu:

a. hak bisa menerima tagihan berdasarkan perjanjian sebelumnya antara penjual dan pembeli terhadap sesuatu yang diperikatkan dalam bentuk apapun;

b. berhak menerima perlindungan hukum yang diberikan dengan niatan baik;

c. memiliki hak untuk dapat menyatakan pembelaan diri jika terjadi sesuatu hal yang tidak diinginkan dalam persoalan hukum konsumen;

d. mendapat pemulihan nama baik ketika dinyatakan bahwa tidak terjadi sebuah tindakan yang merugikan konsumen;

\section{Peran Badan Penyelesaian Sengketa Konsumen (BPSK) dalam Penyelesaian Sengketa Konsumen}

Badan Penyelesaian Sengketa Konsumen (BPSK) berdiri berdasarkan Undang-undang dimana setiap Kabupaten/ Kota wajib dibentuk sesuai perintah undang-undang dan mempunyai tugas pokok dan fungsi untuk menyelesaikan permasalahan konsumen diluar pengadilan (non litigasi) secara murah, cepat, dan sederhana (Shofie, 2002). Ketika dirancang, seperti mengadopsi cara alternative dispute resolution (ADR) khas Indonesia dimana dapat dilihat dari terminologi yang dipergunakan dalam menyelesaikan sengketa konsumen dengan tersedianya 3 (tiga) cara penyelesaian sengketa yaitu secara konsiliasi, mediasi, dan arbitrase. Tujuan pembentukannya yaitu mengatasi persoalan antara pelaku usaha dengan konsumen yang didasarkan pada totalitas yang kecil, akan tetapi tidak memiliki 
batasan antara totalitas yang kecil sampai yang besar sehingga dimungkinkan bagi konsumen menggugat mulai dari nilai terkecil hingga nilai yang besar. Badan ini penting dan dibutuhkan disetiap daerah diseluruh Indonesia khususnya di daerah tingkat dua sehingga konsumen yang merasa dirugikan dapat memperjuangkan keadilan yang dialaminya. Walaupun tidak pengadilan, kehadirannya atas status hak konsumen yang mendapatkan keamanan didalam penyelesaian persoalan konsumen dengan pelaku usaha ataupun sebaliknya, akan tetapi kehadirannya lebih penting untuk menjalankan pengawasan pada pencantuman klausula baku yang dilakukan pelaku usaha demi memberikan motivasi kepatuhan dan kesadaran hukum. Dengan adanya lembaga ini, maka bisa memberikan kepastian hukum kepada pencari keadilan. Setiap konsumen maupun pelaku usaha yang merasa dirugikan dapat mengadukan masalahanya kepada BPSK baik secara langsung atau diwakili oleh kuasanya maupun ahli warisnya. Keberadaan Badan ini dapat diartikan sebagai awal kesetaraan keadilan sebab mustahil nilai yang kecil diselesaikannya konflik secara litigasi dimana tidak seimbang antara kerugian yang dituntut dengan uang yang dikeluarkan. Dalam hal ini bisa dicermati 2 (dua) poin utama.

1. Bahwa Hukum Perlindungan Konsumen menyampaikan preferensi menuntaskan konflik penjual dan pembeli secara Non litigasi di BPSK diluar peradilan sesuai domisili hukum sang konsumen.

2. Mengakhiri konflik antara Penjual dengan Pembeli bukanlah pilihan tertutup. Namun, para pihak diberi kebebasan untuk memilih jalur penyelesaian atas konflik mereka baik secara litigasi maupun secara non litigasi.

BPSK memiliki peran dalam melaksanakan proses dan penuntasan konflik konsumen melalui cara mediasi, arbitrase atau konsiliasi dengan kesempatan yang diberikan mulai dari konsultasi perlindungan konsumen, pengawasan dalam penerapan perjanjian, membuat laporan ke penyidik apabila ada indikasi pelanggaran hukum, menerima pengaduan, melakukan kajian dan analisis konflik yang terjadi, memanggil para pihak, saksi maupun setiap individu yang mengetahui sebuah peristiwa pelanggaran hukum. Apabila Panggilan BPSK tidak dipenuhi, maka meminta bantuan aparat berwenang untuk menghadirkan para pihak termasuk pihak yang dianggap mengetahui adanya peristiwa pelanggaran hukum. Memberikan putusan dan penetapan terhadap yang disengketakan perihal ada ataupun tidaknya kerugian yang dialami oleh para pihak. Dan apabila Pelaku usaha telah diputuskan telah menimbulkan kerugian bagi konsumen maka pelaku usaha akan dijatuhkan sanksi administratif kepada pelaku usaha yang melanggar ketentuan Undang-undang. Dalam proses penyelesaian sengketa yang sedang bergulir, maka dibentuk majelis untuk memeriksa dan memberi putusan dimana majelisnya wajib ganjil dan minimal 3 (tiga) orang terdiri dari seorang ketua merangkap anggota, seorang wakil ketua merangkap anggota, dan seorang anggota. Majelis yang dibentuk memuat komponen eksekutif, konsumen dan pelaku usaha serta dibantu oleh seorang panitera. Putusan majelis bersifat final dan mengikat. Wanprestasi bagian faktor timbulnya konflik akibat salah satu pihak tidak melakukan prestasi atas perjanjian yang telah disepakati oleh para pihak. Konflik antara Konsumen dan Pelaku Usaha dimaksudkan adalah untuk menuntut kerugian yang dialami oleh para pihak baik kerugian secara materil maupun kerugian immateril berefek dari mengkonsumsi barang dan atau manfaat jasa (Suherman, 2004). Bila penulis mencermati melihat secara umum perihal konflik konsumen dengan indikator aturan yang berlaku perihal dengan perlindungan konsumen.

\section{SIMPULAN}

Berdasarkan hasil dan pembahasan di atas, ada beberapa simpulan yang dapat dibuat, yaitu: pertama, pelaku usaha mempunyai kedudukan yang sama di hadapan hukum dan mendapatkan perlindungan hukum dalam menjalankan usahanya. Hal ini diatur dalam asal 1 angka 3 UU No. 8 tahun 1999 mengenai perlindungan konsumen yang menyatakan kalau pelaku usaha itu merupakan orang keseluruhan atau individu ataupun suatu badan usaha yang didasarkan pada hukum atau tidak serta tempat melaksanakan kegiatan tersebut di daerah NKRI. Kedua, akibat perkembangan konflik antara Konsumen dan Pelaku Usaha menjadi penyebab lahir Badan Penyelesaian Sengketa Konsumen (BPSK) dengan tujuan menyelesaikan konflik antara konsumen dan pelaku usaha secara non litigasi dengan efektif dan efisien dan berpayung hukum dengan dasar segala aturan hukum yang berlaku berkaitan dengan hukum konsumen. BPSK memiliki peran dalam melaksanakan proses dan penuntasan konflik konsumen melalui cara mediasi, arbitrase atau konsiliasi dengan kesempatan yang 
diberikan mulai dari konsultasi perlindungan konsumen, pengawasan dalam penerapan perjanjian, membuat laporan ke penyidik apabila ada indikasi pelanggaran hukum, menerima pengaduan, melakukan kajian dan analisis konflik yang terjadi, memanggil para pihak, saksi maupun setiap individu yang mengetahui sebuah peristiwa pelanggaran hukum.

\section{DAFTAR PUSTAKA}

Akhyar, Z., Matnuh, H., \& Hardianto. (2015). Peranan Badan Penyelesaian Sengketa Konsumen (BPSK) Kota Banjarmasin. Jurnal Pendidikan Kewarganegaraan, 5(10), 773-783.

Krisyanti, C. T. S. (2009). Hukum Perlindungan Konsumen.

Kurniawan. (2011). Hukum Perlindungan Konsumen, Problematika Kedudukan dan Kekuatan Putusan Badan Penyelesaian Sengketa Konsumen (BPSK). Malang: UB Press.

Redjeki, H. S. (2002). Aspek-Aspek Hukum Perlindungan Konsumen dalam Kerangka Era Perdagangan Bebas. Bandung: Mandar Maju.

Samosir, A. (2018). Penyelesaian Sengketa Konsumen yang Dilakukan Badan Penyelesaian Sengketa Konsumen (BPSK). Juranl Hukum Legal Standing, 2(2), 133-142.

Shidarta. (2000). Hukum Perlindungan Konsumen.

Shofie, Y. (2002). Penyelesaian Sengketa Konsumen Menurut Undang-Undang Perlindungan Konsumen (UUPK). Bandung: PT. Citra Aditya Bakti.

Suherman, A. M. (2004). Arbitrase dan Alternatif Penyelesaian Sengketa, Aspek Hukum dalam Ekonomi Global. Jakarta: Ghalia Indonesia.

Tumantara, E. F. (2016). Hukum Perlindungan Konsumen (Filosofi Perlindungan Konsumen dalam Persfektif Politik Hukum Negara Kesejahteraan).

Yatini, \& Safitri, W. (2019). Penyelesaian Sengketa Konsumen di Lembaga Badan Penyelesaian Sengketa Konsumen (BPSK) Kota Samarinda. Journal of Chemical Information and Modeling, 53(9), 63-96. 